This is an accepted manuscript of an article published by The University of Wisconsin Press in Éric Méchoulan (ed.) Intermediality (Special Issue), SubStance 138, Vol. 44. No. 3 (2015), 112-127.

\title{
"In the Beginning"... an Intermedial Babel
}

\author{
Karin Littau
}

I think in images. Poems help me to do this. ${ }^{1}$

\section{Am Anfang}

In the Beginning was a major exhibition of Anselm Kiefer's work at the Bundeskunsthalle in Bonn in 2012. The exhibition included, among other works, several large-scale lead book sculptures, and featured Bavel Balal Mabul (2012), ${ }^{2}$ an installation filling an entire room and bringing together many of Kiefer's key themes: mythology, memory, and history; apocalypse, regeneration, and transformation. It shows the tower of Babel in the shape of a spiral staircase-like-structure, spanning from floor (the Earth) to ceiling (the Heavens). Tumbling down the metal stairs are picture rolls that gather at the bottom of the tower like the wastage on the cutting room floor of a photographer's or a movie editor's suite. If we look more closely, we notice that these ribbons of paper are each composed of multiple black and white photographs. ${ }^{3}$ Strung together, the photographs are like a film reel. Each photograph depicts a tower and as a reel they show towers at various stages of (de)composition. The images come from other gigantic installations Kiefer created, including the 
architectural landscape of concrete towers molded from shipping containers at his studio in Bajac, France.

The very name of the Bonn sculpture captures the confusion of languages associated with the Babel myth. The name "babel" (בבל) is a mingling of the letters from the word "balal" (בלל), which in Hebrew means to mix or to confound, while "mabul" (מבול) is the Hebrew word for flood. The work itself is a mesh of different materials and media: a mixed media sculpture of steel, lead, and photopaper. Bavel Balal Mabul is one of several of Kiefer's reworkings of the Babel myth and a title he has used for another sculpture exhibited in Milan in 2012 in the form of a printing press. From this press spill out a tangle of photopapers, which like their Bonn counterpart depict various towers. Juxtaposed here is an old technology (print) and a new technology (photography; film). ${ }^{4}$ It is as if Kiefer is drawing our attention to Marshall McLuhan's famous dictum that 'the 'content' of any medium is always another medium" (15-16). The content of film is photography, the content of photography is painting, or in Kiefer's case, the content of the sculpture is print and film and the content of the photo stills are sculptures.

As the spectator moves around the Bonn installation and takes in its details, the eyes must zoom in on the stills of the picture rolls. Only then can we see the details of the towers. When we step back, zoom out so to speak, we take in the work as a whole, albeit only ever from the partial perspective of where we are standing in relation to the sculpture. While the work is static, simulating movement only in the tumbling of photopaper rolls uncurling across the gallery floor, our movements as spectators around the sculpture, coming closer and stepping back, put the work in 
motion for us. Intermediality here is not only a descriptor for a multi-media artwork like Bavel Balal Mabul, it is also a descriptor of our engagement with it. More than that, intermediality is what this work is arguably about. In the beginning was intermediality. Kiefer's sculpture is the starting point of this essay, because it brings together the three areas I want to explore: mediality, intermediality, and translation.

\section{Intermedial Translation}

Roman Jakobson argued that interlingual (as opposed to intralingual or intersemiotic) translation defined the study of "translation proper" (233). ${ }^{5}$ In the 1990s many translation theorists argued that formalist approaches of this kind tended to overlook the importance of culture as a unit of translation, and therefore proposed intercultural translation as a renewed way of thinking about translation. ${ }^{6}$ I would like to add intermedial translation to this already growing taxonomy, not least because interlingual and intercultural studies of translation have largely been blind to the extent to which mediality is an underlying condition - one might say the a priori - of all cultural output and cultural transfer. This necessitates that we take into consideration not only the particularities and materialities of the medium, or edition, from which and into which a given work is translated, but also inquire into the ways in which successive media technologies such as print, cinema, and computer have arguably engendered new material and aesthetic practices of translation. Intermedial translation - whether between media cultures, from one discrete medium into another, or within a given medium - is not therefore translation improper or marginal to Translation Studies, but vital to its remit in the twenty-first century: to understand the changing role of human communication in an age of rapid technological change. 
Elsewhere I addressed the constitutive role that technologies have played in the history of translation in the media contexts of oral, scribal, print, and digital cultures. ${ }^{7}$ Drawing on insights from historians of the book, who have shown how practices of writing and reading have varied historically in accordance with the material forms available for the storage and retrieval of information, I asked whether these insights are also applicable in the context of translation. If it is the case that material carriers (electricity, human body, tablet, scroll, codex, book, computer) and their hardware (voice, clay, wax, papyrus, parchment, vellum, paper, screen) transformed practices of writing and reading, as Robert Darnton, Roger Chartier, and others have demonstrated, ${ }^{8}$ then, surely, the same carriers and hardware also make a difference to translation. After all, translation partakes in very material ways of both writing and reading. To what extent then do translations bear the traces of their particular technological environment, be this performance-based, artisanal, industrial, electronic, or digital? Did translators translate differently before the codex was introduced as the main vehicle for preserving and transmitting writing? In what ways did the invention of print revolutionize practices of translation? How has the computer altered the practice and theory of translation? My aim, in showing how translation changed over the course of history in accordance with the material and technical resources at its disposal, was to throw new light on age-old debates about word-for-word and sense-for-sense translation.

For this essay, I want to focus on the mediascape of the late twentieth and early twenty-first century, where the shift from print to image dominated media technologies have been felt most keenly. Of course this is not itself a new but rather a repeated phenomenon, constitutive of a media archaeology supporting the history of 
cultural expression. In particular, I want to examine how the medium of film has left its marks on translation. Recent research in film and literature has shown how cinema has affected literature's self-understanding, not least because film has given rise to a host of new literary forms of expression, frequently referred to as cinematic or filmic literature. ${ }^{9}$ I am thinking here of the self-conscious borrowings of filmic techniques, especially montage, in works by John Dos Passos and Alfred Döblin; the parallel, converging interests of literary modernism and cinema in poems by T. S. Eliot or Blaise Cendrars and prose fictions by Virginia Woolf or H.D.; and the appropriations in postmodern fictions, by among others, Thomas Pynchon and Angela Carter, of qualities so readily associated with cinema, such as surface, depthlessness, and simulation. If film has productively transformed, even invigorated, literary practice, might this not also be the case with regard to literary translation? In what ways has film shaped the material and aesthetic practices of translation? For instance, what kinds of filmic techniques have been absorbed into poetry translations in book-form or for online e-translations? How are we to understand the allusions to film and film culture in translations based on originals that were composed before film was even invented? My aim in exploring these questions, is firstly to demonstrate that media shape minds or "mindsets," and secondly to show, through two specific instances, how translation too is affected by what Thomas Elsaesser has called the "cinema in our heads" (107). The two examples of what might be called filmic translations are: Christopher Logue's War Music (2001) freely translated from the Illiad and Norbert Hummelt's 2008 translation into German of T.S. Eliot's The Waste Land (1922). By filmic translation I do not mean adaptation, the transposition from literature into film, or vice versa. ${ }^{10}$ Rather, I mean the way in which translation has adapted to film culture. 
Here, I want to take seriously Bertolt Brecht's claim from 1931 that "The film viewer reads stories differently. But the person who writes stories is for his part also a film viewer" (113). The translator does of course both. She or he reads an original in one language and writes it down in another. Logically, then, the person who translates literature in the age of screen culture is not only shaped by a bibliographic but also by a cinematic imagination. Made in the context of a discussion of the ways in which old media (books) are affected by the arrival of new ones (films), and cannot exist alongside them unchanged, Brecht's claim is an early acknowledgement of how media compete and adapt to one another. It is also one of the first articulations of intermediality, that is, the idea that media bear one another's traces, and are impoverished if they are treated in isolation from one another. Another direct address of this issue is found three decades later in the aforementioned McLuhan's quote from Understanding Media (1964). As McLuhan elaborates: "The content of writing is speech, just as the written word is the content of print, and print is the content of the telegraph" (14-15). Later in the book he relates this directly to film: "The content of a movie is a novel or a play or an opera" (26). On the one hand, this suggests that an older medium lives on in a newer medium and is therefore not supplanted; on the other hand, as McLuhan also insists, this means that the content of a medium, say the story of a given film, is less important than the message of the medium. And this message is "that media as extensions of our senses institute new ratios, not only among our private senses, but among themselves, when they interact among themselves" (63). ${ }^{11}$ This point is crucial to an understanding of media change and the effects of media on the human sensorium. It explains how the economies of scale of the printing press, the sensory barrage of motion pictures, or the instantaneity of 
networked computing have impacted on our senses, perception, and cognition. In turn, it explains how our forms of expression and cultural outputs - which include translation - are shaped by the media ecology which thinking bodies inhabit. That there is no thinking or thought that is not consequent upon some medium, can be summed up in one word: mediality.

\section{Mediality}

The late twentieth-century preoccupation in Media Studies with popular culture, representation studies, and ideology critique has given way to a mediaphilosophical discourse about the role of technology in human evolution that now propels a significant amount of research in the Humanities more generally. With its coupling of the human and the technological, this version of media study takes its cue from Canadian and German media theory, in particular, McLuhan and Friedrich Kittler, who takes from McLuhan the idea that "media," as Kittler puts it "determine our situation." 12 While mediality has become a core concern in recent AngloAmerican media theory, ${ }^{13}$ little has been said outside of French- and Germanspeaking media scholarship about its correlate term: intermediality. ${ }^{14}$ There is, however, a pressing historical and theoretical imperative for treating both concepts together. If we accept McLuhan's point that "the 'content' of any medium is always another medium" (emphasis added), that is to say, that media "remediate" each other, to use Jay David Bolter and Richard Grusin's term, ${ }^{15}$ it follows that intermediality is as old as media themselves. Arguably therefore, the concept of mediality presupposes an a priori intermediality. 


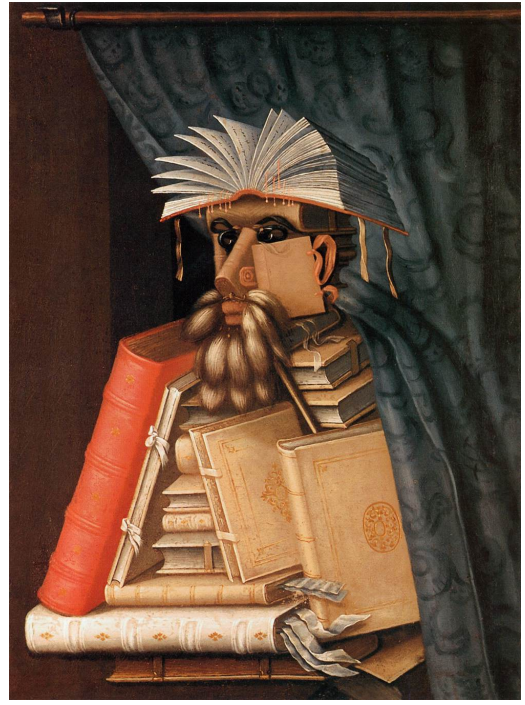

Figure 1

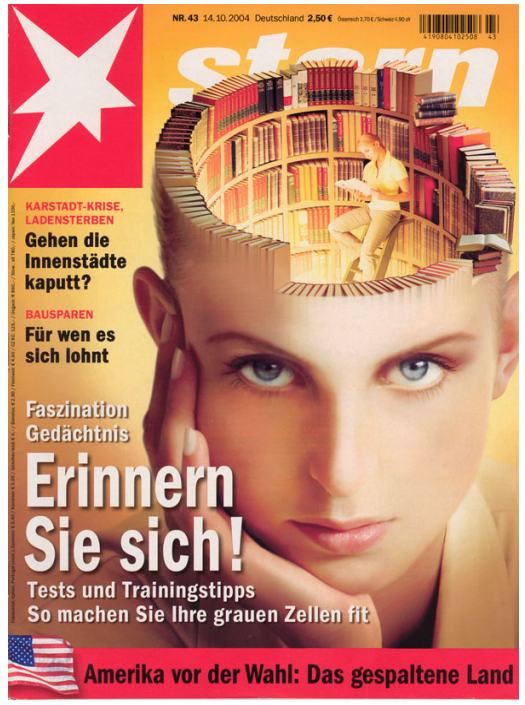

Figure 2

In order to explore this claim more concretely, I will focus on a number of images that are mediated reconstructions of thought-worlds, which we might call "mind-sets." As Kittler has shown in Optical Media (2010) there is a "historical tendency to employ technical media as models or metaphors for imagining the human or the soul" (35). This is evident in the ways in which mind has variously been described as a wax tablet (Plato), a blank sheet of paper (Locke), a palimpsest (de Quincey), or camera obscura (Leibniz). ${ }^{16}$ In Figures 1 and 2, for instance, the mind is conceived as "bookish," and therefore clearly the product of writing and print culture. Giuseppe Arcimboldo's painting The Librarian (ca. 1566) and the cover from the glossy magazine Stern (14 October 2004) entitled "Do you remember?" invoke the art of memory and how we access it; here, aided by the indexed book or library which makes information easily retrievable. These images also imply that the imagination is bibliographic. It is as if both images embrace what Kant warned of, namely, to make one's "head into a parchment.",17 


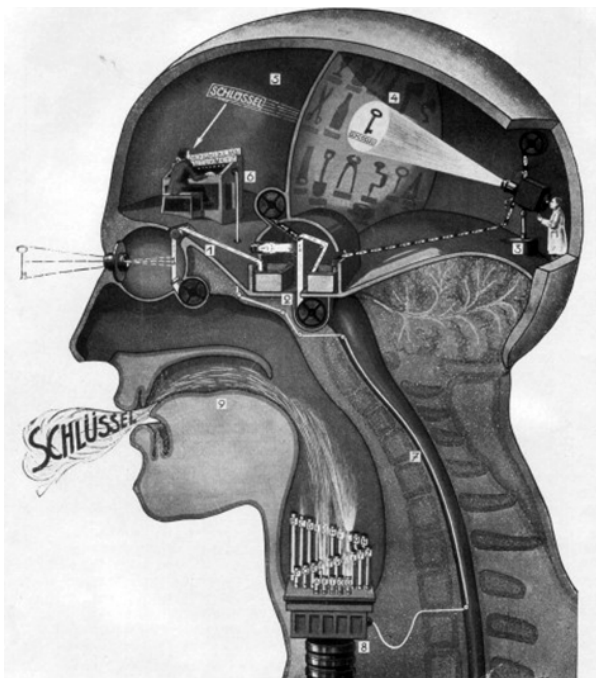

Figure 3

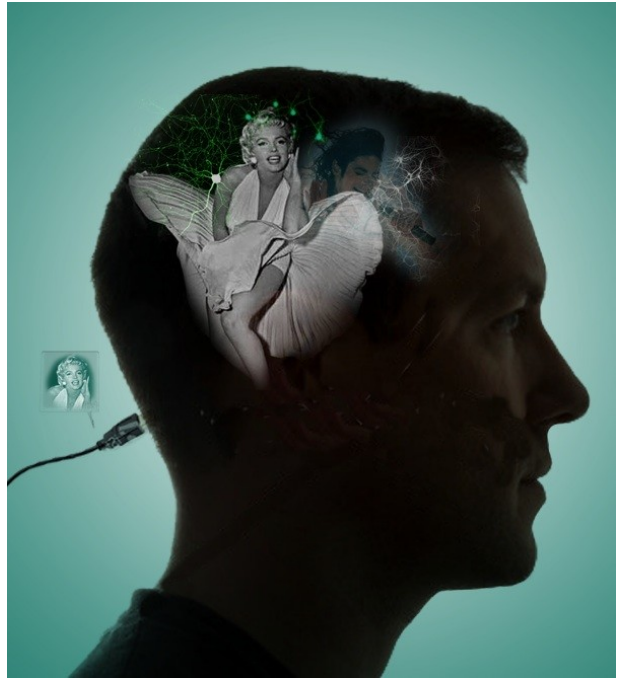

Figure 4

Contrastively, Figures 3 and 4 represent the mind in proto-cinematic terms, thus undermining the assumption that the contemporary thought-world is dominated by print culture. Fritz Kahn's “The Act of Seeing” (1926) first published in the year that silent film was first challenged by the talkies shows a mind that has internalized the cinematic apparatus. That "filmic perception" 18 has pervaded all aspects of our thinking is also evident in Figure 4, which is a visual representation of a "new advance in brain/machine interface," according to Bryner, that "could enable scientists to one day decode what a person is thinking simply by monitoring brain cell activity". As the study co-author Moran Cerf, a computational neuroscientist at UCLA, told TechNewsDaily: "Now we actually are able to read people's mind, on a very small subset of things, but you can still read their minds. ${ }^{, 19}$ By using an iconic still of Marilyn Monroe from the movie The Seven Year Itch (1955), Figure 4 shows us a movie-minded head realized as a neurophysiological cinema; ${ }^{20}$ it also however displays this mind in transition: a mind at once mediated by photography and motion pictures, and plugged into a computer. 


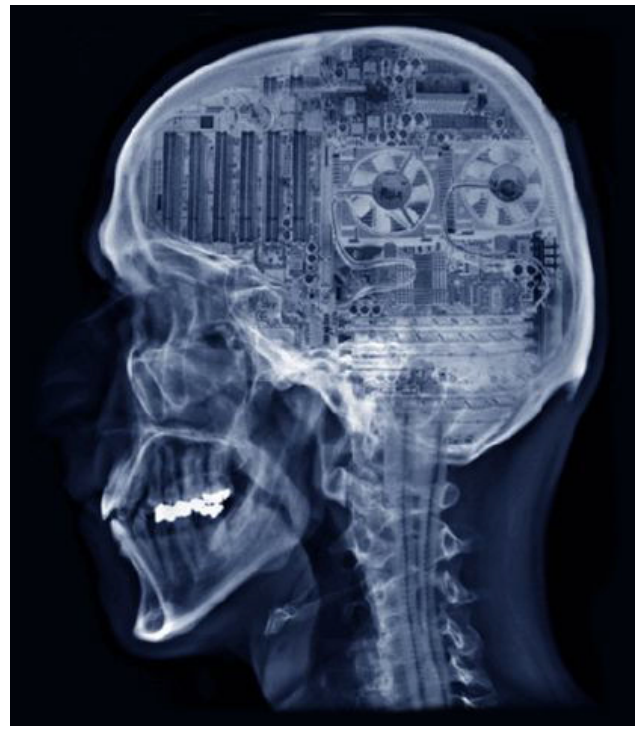

Figure 5

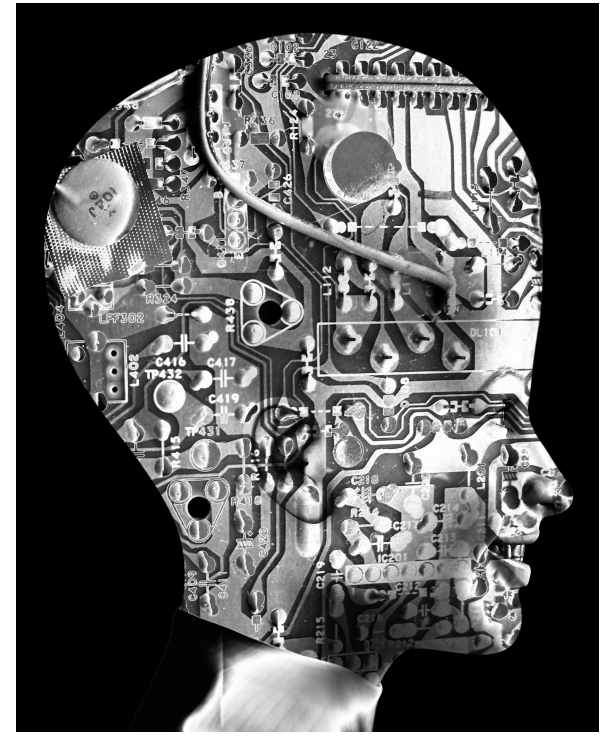

Figure 6

The cyborg connotations of Figure 4 are graphically realized in Figures 5 and $6,{ }^{21}$ where mind has updated to a computer. Mind here is no longer bookish or cinematic but "computerish," as if to enact Lev Manovich's point that "the computerization of culture" (14) has pervaded all aspects of our thinking. These brains resemble the circuits of electronic media, remediated via the medium of another, older technology, namely x-rays. The shift from book-head to cinema-mind to computer-brain, and finally in Figure 6 to a virtual reality simulated non-human android suggests, firstly, that cognitive functions such as thought and memory are successively remodeled in accordance with a historically specific medium and, secondly, that as technologies multiply, so do our models for understanding the mind. This raises three related questions. Firstly, is the psyche only ever shaped by the latest technologies? Does a brain suddenly stop being "bookish-minded" with the birth of the motion pictures and has mind now irrevocably transformed from a "motion picture" into a "computer"? Secondly, therefore, are the inner workings of the mind as medium-specific or mono-medial as these metaphors suggest? And thirdly, what does 
it entail for the humanities (or the Geisteswissenschaften) to say that mind or spirit (Geist) is "spoken" by technology?

What is explicit in Figure 5, although implicit in the other figures with the exception of the Arcimboldo painting, is that the inner workings of the mind can only be made externally visible by recourse to an unseen technology. The heads, each with its own "mind-set," may appear to show a simple linear relation between a given technology and habits of thought; however, the heads are possible only on the basis of a technology that enframes them but is not figured in them. That technology is the $\mathrm{x}-$ ray or the CT scan, because it allows us to look into the inside of the head. In consequence, the head is not the environment in which mono-medial relations to thought are played out; but rather, is environed by multiple media in which the head merely counts as one more medium, albeit an older one.

The idea that media technologies are internalized by the mind, or as Walter Ong put it, have been "interiorized, incorporated into mental processes themselves" (172), and in consequence shape thinking, how thinking itself thinks of thinking, and how thinking thinks about the human brain, presents a serious challenge to humanism and its tendency to put the human at the center of all things. In media-philosophical terms this is best encapsulated by Friedrich Nietzsche's observation (1882) about his typewriter: "Our writing instruments also work on our thoughts" (172). This suggests that our instruments, tools, and media change not only the ways in which we write, or translate, but also the matter, form and content of this writing. Tools therefore are not merely a support system, or a prosthetic or "extension of man," as Marx, Bergson, and McLuhan all argued, but determine the "enframing" to which what we assume to 
be separable content is, as it were, a priori subject. This is where Nietzsche's point differs from Heidegger's in the latter's essay on "The Question Concerning Technology." 22 This enframing, or engulfing without awareness, is the root of Heidegger's concern, rather than some luddite protest against telephony or Sputnik. ${ }^{23}$ The logic of Nietzsche's insight is this: if tools work on our thoughts it follows that the thought of the separability of tool from thought is itself the work of those tools. We cannot think without tools or outside of them; they environ thought and mediate it accordingly.

This line of thinking suggests a radical rethinking of mental worlds. As David Wellbery sums up Kittler's project, which is derived from Nietzsche's observation about his typewriter and which he uses as a deliberate provocation to the Geisteswissenschaften in general and the Medienwissenschaften in particular: it is not Geist but media that "set the framework within which something like 'meaning,' indeed, something like 'man,' become possible at all" (xii). ${ }^{24}$ In other words, media are central to the production of culture and their self-understandings. They give a body to the mind's labors, and make it possible to take these labors out into the world to be shared by others. Without media, the labors of human imagination could neither be stored nor transported or transmitted. Crucially then media do more than merely serve (they are not just neutral bearers of social, artistic or constructive meaning) and do more than merely conserve (they are not just storage systems): they are constitutive of the cultural memory and practices they store. They think for us and as us (not with us) when we write, read, and translate. As media historians Aleida and Jan Assmann (1990) explain: 
Everything that can be known, thought and said about the world is only knowable, thinkable, and sayable dependently upon the media that communicate this knowing. [...] It is not the language in which we think, but the media in which we communicate that model our world. (2, my translation)

This displacement of the centrality of language to the modeling of the world is nothing other than a displacement of one medium by another. It is a displacement of the medium of language by other, technological media and a displacement of the poststructuralist claim that we are spoken by language and that we cannot think outside language. And yet, as McLuhan has taught us, a new medium always assumes functions presupposed to be specific to the old medium it supplants, and the sense of ourselves it supported. Accordingly if, as Nietzsche noted and McLuhan would concur, media act - via the sensoria they serve to complexify - on our thinking, the thinking this produces must also act in thinking about these media. If media model the world, then the writing of media history, or any history, including the history of translation, is never not touched by the media that shape thinking.

If mediality is a priori, as I have suggested with reference to the metaphors of mind above, it is also historical. Therefore, if mediality - to borrow Michel Foucault's term - is an "historical a priori" (126), we are facing a paradox. An a priori is by definition prior; if historical then it cannot be prior, for this would imply that it is variable. If all that a priori means is that it is first, then adding "historical" to it, is adding nothing, since by definition anything following the first would be historical. This is why it must mean something else. The paradox then is this: being prior, although itself historically variant, does not for that reason unseat the prior from the 
position of being precisely prior. Foucault's point therefore is not "because historical therefore not a priori" but rather: "both historically variant and nevertheless a priori". In the context of mediality this suggests that if both - historically variant and nevertheless a priori - then the historical succession of variant media together constitute an intermedial a priori, i.e. one that cannot be reduced to a single medium such as thought, print, film, computer, etc.

\section{"Filmic" Translation}

Writing and the literary arts are the products of material conditions; however, these material conditions are not reducibly social but as Marx suggests in $1857 / 8$, they are also technological and medial.

Is Achilles possible with powder and lead? Or the Illiad with the printing press, not to mention the printing machine? Do not the song and the saga and the muse necessarily come to an end with the printer's bar, hence do not the necessary conditions of epic poetry vanish? (111)

Marx is articulating a series of questions that go to the heart of the issues so far discussed, namely that when material conditions change, so do our cultures' outputs. With reference to translation this means, for instance, that although Pope's age no longer produced its own song and saga, Pope was nevertheless able to translate the Illiad into verse, drawing fully on the poetic resources of his time. In a century dominated by media like film, however, this kind of translation, as Reynolds has pointed out, is out of tune. And yet, this is the challenge that Logue's Illiad translation, War Music, meets head-on, but "in the opposite way," according to 
Reynolds: "In order to write a long poem deriving from Homer, he adopts the tactics of those media that have helped make a long poetic translation impossible" (224). In consequence, Logue imbues his translation with a "cinematic' quality." ${ }^{25}$ In his version of the Illiad, as the blurb on the book cover by Derek Mahon of The Observer makes clear, "The comparison isn't with other poems, or even with prose, but with film: one is reminded of, say, Kurosawa's Kagemusha;" or, as Alan Brien from the New Statesman, in another blurb that deliberately makes film a selling point for this edition, puts it: "Logue seems everywhere at once, like a camera in a helicopter, continually varying close-up and long shot, description and comment [...] War Music is at once an ancient and a modern poem, a triumph of virtuoso rhetoric."

Thus, cinematic techniques like the establishing shot and the zoom become part of the very structure of the Logue translation. For instance, the opening lines of "Kings" are handled in this manner.

Picture the east Aegean sea by night,

And on a beach aslant its shimmering

Upwards of 50,000 men

Asleep like spoons beside their lethal Fleet./

Now look along that beach, and see $[\ldots]$

Then through the gate a naked man $[\ldots]$

Then kneel among those panes, burst into tears, and say:/

'Mother,

You said that you and God were friends. [...]' (7) 
The wide shot of the sea gives way to a zoom that progressively moves closer (the beach; the gate) until we are given a close-up of the speaker, who we learn on the next page is Achilles. As Logue himself puts it in a medial mingling of theater and film: "There is no time to waste in a narrative poem.... Get the stuff on the stage. Stage the action... I think going to the cinema a lot, reading film scripts, and writing for cinema, has made this very clear to me." ${ }^{, 26}$ It is tempting of course to see this update of Homer as a pandering to a modern media-savvy audience, especially in the passage that describes a duel between Menelaus and Paris, where the latter is knocked "backwards through the air" and Logue adds, "Bent like a gangster in his barber's chair" (118). As Reynolds comments, phrases like this are likely to conjure up Francis Ford Coppola's The Godfather with the double-edged effect that "we will see with our imagining eyes the film they call to mind" (228) and recognize the artificial mediatized overlay that imbues this translation of an ancient work with "readyformatted pictures from the push-button store of our cultural imaginary" (228). But this is not the point I wish to make here. Nor do I wish to suggest, as Christopher Reid does in his introduction to War Music, that the Illiad, because translated by a screenwriter, is cinematic for precisely this reason. ${ }^{27}$ Rather, I would like to take seriously a recollection by Logue from his autobiographical writings, unrelated to War Music, that describes how his "brain took on a life of its own:"

I do not doubt those who say that when they have found themselves on the verge of a sudden, unexpected death, their past lives have flashed before their minds. This fractured, babbling film, projected inside my head, was akin to their experiences. ${ }^{28}$ 
This suggests, like the graphic illustrations of the heads in Figures 1-6, that mind cannot think outside media because it inhabits them. Media immerse and mediate, that is, they are immediate for us. While film is clearly part of our cultural imaginary, it is also a shaper of imaginations. Therefore, if mind is an effect of a given media culture, this suggests that media, like film, "no doubt also determine, and hence configure, our intellectual operations, ${ }^{29}$ and this includes writing and translating.

This is also true of T.S. Eliot's The Waste Land, a famously fragmentary poem, which presents us with a "heap of broken images" ("Burial of the Dead") and cacophony of voices. In this respect the poem draws on the two media of its day: cinema and radio. As Harriet Monroe already noted in 1923, a year after The Waste Land was published,

this poem surprises with an effect of unstudied spontaneity. While stating nothing, it suggests everything that is in his rapidly moving mind, in a series of shifting scenes which fade in and out of each other like the cinema. The form, with its play of many-colored lights on words that flash from everywhere in the poet's dream, is a perfect expression of the shifting tortures in his soul. (329-330)

Monroe compares the metal processes of the poem's speaking persona to the moving pictures. Similarly, the montage-like structure of the poem, even if not borrowed consciously from film art, is part of an early twentieth-century mind-set already rewired by the experience of railway-travel and cinema, both of which the cultural historian Wolfgang Schivelbusch associates with hasty, fragmentary and 
impressionistic modes of seeing. Crucially then, what Monroe appears to be saying is that the content of this poem is another medium, film. This demonstrates that this is not a point that issues from McLuhan; rather, the theory issues from a long recognition of intermediality.

Hummelt's translation of The Waste Land as Das öde Land (2008) also brings film into the mix. In "The Fire Sermon" section of the poem, which spells out the effects of mechanization on the "human engine," we meet a typist whose sexual encounter with a clerk has left her cold and dissatisfied:

She turns and looks a moment in the glass,

Hardly aware of her departed lover;

Her brain allows one half-formed thought to pass:

"Well now that's done: and I'm glad it's over."

When lovely woman stoops to folly and

Paces about her room again, alone,

She smoothes her hair with automatic hand,

And puts a record on the gramophone.

The line "When lovely woman stoops to folly" is from a song from the eighteenthcentury popular novel The Vicar of Wakefield. Hummelt translates it with a reference to the Hollywood film, Pretty Woman (1990) starring Julia Roberts: "Wenn Pretty Woman sich getäuscht hat" ("When Pretty Woman has fooled herself"). There is a mixture here of English and German, echoing the multiplicity of languages and intertextual quotations in The Waste Land; and the filmic is sutured into Eliot's sonic 
mediascape that is replete with echoes of songs, radios and gramophones. In Hummelt, aural memory of a song is re-recorded as visual memory of a film. This seemingly superficial change makes explicit a mediascape that was always implicit in the original. As Thomas Elsaesser has argued, "The cinema is part of us, it seems, even when we are not at the movies, which suggests that in this respect, there is no longer an outside to the inside: we are already 'in' the cinema with whatever we can say 'about' it!" (76) We are not only in the cinema, but the cinema is in us: as Elsaesser says this is the "cinema in our heads" (107). This is relevant here, precisely because what Hummelt shows us is that cinema was in the typist's head, just as Monroe shows us that cinema was on the mind of the poem's speaking persona. The changes that Hummelt makes to The Waste Land can be explained thus: there is no translation without mediation; but there is also no translation that is not the product of a prior intermedial relation.

\section{"And to make an end is to make a beginning" 30}

The computer as a convergence medium, it is said, is "the medium to end all media." ${ }^{31}$ This would spell the end of media history and bring intermediality to an end, to complete Babel. But this is not the trajectory I want to take. According to Alan Turing in 1950, a computer is a "universal" machine that can "mimic" any discrete machine. It is universal because there is no machine it cannot mimic, yet does nothing itself until some task is given to it. Any such task will therefore be a repetition of a task hitherto conducted by other machines or media. That makes digital media second order or meta-media, repeating - that is, remediating - the outputs and tasks once conducted in other media: book, film, etc. We can see this at play in innovative digital translation-works, such as by John Cayley or Young-Hae Chang Heavy Industries that 
use the affordances of digital mediation to blur the lines between literature and film. Using morphing and flashing techniques derived from film and film-related media (photographic, tachistoscopic f.i.), these multilingual online translations make visible the translation process on the screen. By so doing they turn translation into a protocinematic experience.

What is new and innovative about these works is "therefore also old and familiar" insofar as "they promise the new by remediating what has gone before." 32 But remediation does not exhaust the possibilities of the computer. Everything here hinges on the computer's universality: because the computer is a universal machine, it repeats, that is, it instantiates the entire history of media in the present; but it also, precisely because it is a universal machine, contains within itself as yet uninstantiated media possibilities, which will be the future. To grasp the changes that translation is undergoing at this, or any other, moment in history therefore requires a comparative understanding of its relations to the mediascapes of the past, present, and future. It is not just that "we" inhabit a heavily mediated environment; rather, the lesson of the heads is the historical actuality of the remediations of mind. Media history has neither come to an end, nor does it exorcise spirit, ${ }^{33}$ but rather stages its intermedial odyssey. 


\section{Works Cited}

Assmann, Aleida, and Jan Assmann. "Schrift - Kognition - Evolution," in E. A. Havelock, Schriftlichkeit. Das griechische Alphabet als kulturelle Revolution. Ed. and intro. A. and J. Assmann. Weinheim: VCH, Acta Humanoria, 1990. 135.

Bolter, Jay David, and Richard Grusin. Remediation: Understanding New Media. Cambridge, Mass.: The MIT Press, 1999.

Brecht, Bertolt. "The Three Penny Trial: A Sociological Experiment.” Trans. L.W. Garmer. German Essays On Film. Eds. R.W. McCormick \& A. Guenther-Pal. New York \& London: Continuum, 2004. 111-132.

Foucault, Michel. The Archaeology of Knowledge. Trans. A.M. Sheridan Smith. New York: Pantheon Book, 1972.

Heidegger, Martin. The Question Concerning Technology and Other Essays. Trans. and intro. William Lovitt. New York and London: Harper Colophon, 1977.

Eliot, T.S. The Waste Land. Das öde Land. Trans. Norbert Hummelt. Frankfurt: Suhrkamp, 2008. 
Elsaesser, Thomas. "The New Film History as Media Archaeology.” Cinémas : revue d'études cinématographiques / Cinémas: Journal of Film Studies 14. 2-3 (2004): 75-117.

Jakobson, Roman. "On Linguistic Aspects of Translation.” On Translation. Ed. Reuben A. Brower. New York: Oxford University Press, 1966. 232-239.

Kahn, Fritz. Berliner Illustrierte Zeitung, 31 Oct. 1926. 1468; rpt. in Fritz Kahn. Ed. Uta von Debschitz and Thilo von Debschitz. Köln: Taschen, 2013. 348.

Kant, Immanuel. On History. Ed. Lewis White Beck. New York: Macmillan, 1963.

Kiefer, Anselm. “Acceptance speech.” Online at: http://www.friedenspreis-desdeutschenbuchhandels.de/sixcms/media.php/1290/2008\%20Peace\%20Prize $\% 20$ Speeche s.pdf

Kittler, Friedrich. A. Discourse Networks 1800 / 1900. Trans. M. Metteer with C. Cullen. Stanford: Stanford University Press, 1990.

--- Film, Gramophone, Typewriter. Trans. Geoffrey Winthrop-Young and Michael Wutz. Stanford: Stanford University Press, 1986.

--- Optical media. Trans. by Anthony Enns and Intro. by John Durham Peters. Cambridge: Polity Press, 2010. 
Logue, Christopher. Prince Charming: A Memoir. London: Faber and Faber, 1999.

--- War Music. An Account of Books 1-4 and 16-19 of Homer's Illiad. London: Faber and Faber. 2001.

Manovich, Lev. The Language of New Media. Cambridge Mass.: The MIT Press, 2001.

Marx, Karl. Grundrisse. London: Penguin, 1973.

McLuhan, Marshall. Understanding Media. The Extensions of Man. London: Routledge \& Kegan Paul, 1964.

Monroe, Harriet. “A Contrast.” Poetry Magazine xxi (March 1923): 325-330.

Nietzsche, Friedrich. “An Heinrich Köselitz in Venedig.” In Briefwechsel. Kritische Gesamtausgabe, Vol. III.1: Briefe von Nietzsche: 1880-1884. Eds. Giorgio Colli and Mazzino Montinari. Berlin: Walter de Gruyter, 1981.

Ong, Walter J. Orality and Literacy. The Technologizing of the Word. London: Methuen, 1982.

Reynolds, Matthew. The Poetry of Translation. From Chaucer \& Petrarch to Homer and Logue. Oxford: Oxford University Press, 2011. 
Schivelbusch, Wolfgang. The Railway Journey. The Industrialization of Time and Space in the 19th Century. Leamington Spa: Berg, 1986. 42

Turing, Alan. “Computing Machinery and Intelligence.” In The New Media Reader. Eds. Noah Wardrip-Fruin and Nick Montfort. Cambridge, Mass.: The MIT Press, 2003. 50-64.

Wellbery. David E. "Foreword.” In Friedrich A. Kittler, Discourse Networks 1800 / 1900. Vii-xxxiii.

Winthrop-Young, Geoffrey, and Michael Wutz. “Translators' Introduction.” Friedrich A. Kittler. Gramophone, Film, Typewriter. Xi-xxxviii.

\section{Notes}

\footnotetext{
1 Anselm Kiefer's “Acceptance speech” (9) for the 2008 Peace Prize of the German Book Trade, which for the first time was awarded to a fine artist. See 2008 Peace Prize Speeches: http://www.friedenspreis-des-deutschen-buchhandels.de/445950/ 2 See http://www.art-magazin.de/kunst/52268/anselm_kiefer_bonn?cp=5 for a photograph of the sculpture exhibited in Bonn.

3 See http://www.androgon.com/11678/kultur/kunst/anselm-kiefer-am-anfang for a close-up of the photo paper rolls.
} 
4 When compared with Jakob Gautel's book sculpture Babelturm (2006) or Marta Minujin's La Torre de Babel Con Libros de Todo El Mundo (2011), both of which belong to a bibliographic imagination, Kiefer's Babel sculptures - we might say belong to a cinematic imagination. Put differently, Minujin's sculpture, which was commissioned when UNESCO named Buenos Aires "World Capital of Books" for 2011 and is comprised of 30,000 books in over 54 languages, celebrates the multiplicity of writings in different languages (rather than mourning the loss of one language) and with it the Book as a symbol of culture, by contrast, Kiefer's Babel sculptures thematize the transitions between media cultures, which might be understood as a form of diachronic intermediality.

5 For a critique of Jakobson's notion of “translation proper," see Jacques Derrida. “Des Tours de Babel.” Trans. Joseph F. Graham. Difference in Translation. Ed. Joseph F. Graham. Ithaca New York: Cornell University Press, 1985. 165-248.

6 See Susan Bassnett, and André Lefevere, eds. Translation, History and Culture. London: Pinter, 1990.

7 Karin Littau. "First Steps Towards A Media History Of Translation.” Translation Studies 4.3 (2011): 261-281.

8 Robert Darnton. The Kiss of Lamourette. London: Faber and Faber, 1990; Guglielmo Cavallo, and Roger Chartier, eds. A History of Reading in the West. Trans. Lydia G. Cochrane. Cambridge: Polity Press, 1999.

9 See Julian Murphet, and Lydia Rainford, eds. Literature and Visual Technologies: Writing after Cinema. Houndmills: Palgrave Macmillan, 2003; David Seed, ed. Literature and the Visual Media. Cambridge: D.S. Brewer, 2005; Laura Marcus, The Tenth Muse. Writing about Cinema in the Modernist Period. Oxford: Oxford UP, 2007; David Trotter, Cinema and Modernism. Oxford: Blackwell, 2007. 
${ }^{10}$ A fascinating example of intermedial translation is Angela Carter's 1996 rendition of Lulu by Frank Wedekind, into which she weaves aspects of the play's film adaptation by G. W. Pabst (1929) as well as film-historical and film-theoretical insights.

${ }^{11}$ Mention should be made here of some of the criticisms of McLuhan, namely that his work lacks a socially constitutive moment and that for this reason he cannot account for the socially constitutive moment from which he writes, hence a lack of reflexivity about his position. The point that his theory is largely unsubstantiated (that it is literary and avant-gardish rather than scholarly or empirical), however, may be answered by addressing the previous point. Since McLuhan is concerned with the medium being the "massage," his probes consist precisely in a mediumspecific reflexivity as regards a given medium's affordances, capacities, and constraints. Accordingly, McLuhan could be argued to be as reflexive as his investigations are specific. The real anxiety underlying such concerns has to do with technological determinism. However, as Iain Grant argues, this is a fear of determinism that requires but does not supply an appropriate address to the modes of causality. In consequence, Grant develops an account of technological determinism that is quite different to that which Raymond Williams, for instance, ascribes to McLuhan: deploying not the logic a mechanical causality but of nonlinear causality. See Grant, Chapter 5. "Cyberculture: Technology, Nature and Culture". In Martin Lister, Martin et al., New Media: A Critical Introduction. London and New York: Routledge. 287-382.

${ }^{12}$ Kittler, "Preface". Gramophone, Film, Typewriter, xxxix

${ }^{13}$ For a field-defining anthology, see W.J.T Mitchell, and Mark B.N. Hansen, eds. Critical Terms for Media Studies. Chicago: Chicago University Press, 2010. For a 
precursor of the approaches in this anthology, see the seminal volume by Hans

Ulrich Gumbrecht, and K. Ludwig Pfeiffer, eds. Materialities of Communication.

Trans. W. Whobrey. Stanford: Stanford University Press, 1994, which in large part is based on an earlier volume, Materialität der Kommunikation. Frankfurt am Main: Suhrkamp Verlag, 1988.

${ }^{14}$ For representative work in this field, see the Canadian journal Intermédialités: histoire et théorie des arts, des lettres et des techniques / Intermediality: History and Theory of the Arts, Literature and Technologies, and the substantial 600 page volume edited by Joachim Paech, and Jens Schröter, Intermedialität - Analog /Digital. Theorien - Methoden - Analysen. München: Wilhelm Fink, 2008.

15 "Remediation" updates McLuhan's point. More specifically, it is used by Bolter and Grusin to refer to the way in which one particular medium "appropriates the techniques, forms, and social significance of other media and attempts to rival or refashion them in the name of the real." (99). It should also be noted that Bolter sees "remediation" as part of "the larger project of intermediality." See "Remediation and the Language of New Media." Northern Lights 5 (2007): 25-37 (26).

16 See Plato. Phaedrus. Trans. H. N. Fowler. Cambridge, MA, Harvard University Press \& London, William Heinemann Ltd, 1925. 405-579; John Locke, An Essay Concerning Human Understanding. Oxford: Oxford University Press, 1975. 104; Thomas de Quincey. Confessions of an Opium-Eater and Other Writings. Ed. by Robert Morrison. Oxford: Oxford University Press, 2013. 135. Gottfried Wilhelm Leibniz. New Essays on Human Understanding. Abridged Edition. Trans. Peter Remnant and Jonathan Bennett (Cambridge: Cambridge University Press, 1982). 145. For two excellent works on metaphors of mind, see Jonathan Crary. 
Techniques of the Observer. On Visions in the Nineteenth Century. Cambridge: The MIT Press, 1992, and Aleida Assmann, Erinnerungsräume. Formen und Wandlungen des kulturellen Gedächtnisses. München: C.H. Beck, 1999.

17 Kant cited by Lewis White Beck, On History, vii.

18 See Schivelbusch. The Railway Journey, 42.

19 See Michelle Bryner, "New Brain reads Minds." 2010. Online at: http://www.nbcnews.com/id/39872780/ns/technology_and_sciencetech_and_gadgets/t/new-brain-machine-reads-minds/\#.VRfgtEuvvHg

${ }^{20}$ Reproduced by kind permission of the illustrators of the graphics, Moran Cerf and Maria Moon. See Cerf et al. "On-line, Voluntary Control of Human Temporal Lobe Neurons." Nature 467 (2010): 1104-1108.

21 “Fully Upgradeable,” http://www.worth1000.com; "Computer Head 35 Photo," http://www.dreamtime.com.

22 As Geoffrey Winthrop-Young and Michael Wutz point out in their “Translators' Introduction" to Kittler's Gramophone, Film, Typewriter: in Kittler's work, “Heidegger's notion of technology as Gestell, a supportive framing of human being, turns out to be an entire Ersatz for human being" (xxxiv).

23 See Heidegger. On the Way to Language. Trans, Peter D. Hertz. New York: HarperCollins, 1982, where he says that "Metalanguage and sputnik, metalinguistics and rocketry are the Same" (58).

24 The inverted quotations which frame "man" is a reference to Kittler's recurring and derogatory refrain of "so-called Man" (16) in Gramophone, Film, Typewriter. It indicates that if minds are substantially changed then the contents of thoughts, such as what is "meaning" and what is "man," must itself change.

25 David Ricks, quoted in Reynolds, The Poetry of Translation, 224. 
${ }^{26}$ Logue, quoted in Reynolds, ibid., 225.

${ }^{27}$ Reid. “Introduction. Logue's Homer, Homer's Logue.” In Christopher Logue, War Music, Xi-xii (xii).

${ }^{28}$ Logue. Prince Charming, 156.

${ }^{29}$ Winthrop-Young and Wutz, xx.

30 T. S. Eliot, Four Quartets (1943).

31 Winthrop-Young and Wutz, xxx.

32 Bolter and Grusin, 270.

33 In this context, see Kittler, Austreibung des Geistes aus den Geisteswissenschaften. Paderborn: Ferdinand Schöningh, 1980, which translated literally means Exorcism of the Spirit from the Spirit Sciences, but is perhaps best rendered in English as Driving-out of the Human from the Human Sciences. 